Ann. Zootech., I979, 28 (3), 25r-260.

\title{
Machine milkability as related to dairy yield and its fractions in dairy ewes ( ${ }^{1}$ )
}

\author{
O. JATSCH and R. SAGI \\ Institut für Tievzucht und Haustiergenetik der Justus-Liebig-Universität, \\ Giessen, Federal Republic of Germany \\ Faculty of Agricultural Engineering, Technion, Haifa, Israel
}

\begin{abstract}
Summary
The effects of breed, rearing method, udder conformation, udder consistency, lactation number and stage of lactation on milk yield and adaptation to machine milking were evaluated by determining milk yield fractions for Awassi and Assaf dairy ewes.

Although udder conformation for some ewes changed with lactation stage, differences in udder conformation significantly affected milk yield and adaptation to machine milking, while breed, rearing methods and udder consistency had non-significant effects. Adaptation to machine milking decreased with increasing age and stage of lactation. When selecting ewes for improved machine milkability, one should consider these relationships.
\end{abstract}

\section{Introduction}

Improvement in machine milkability, i.e., completeness of milk removal, and in milking efficiency, i.e., the number of ewes milked and the amount of milk obtained per man-hour, is of important economic benefit to dairy sheep farming. The goal of everyone associated with sheep milking is to achieve complete removal of milk by machine with little or no stripping.

Machine milkability of ewes, and efficiency of milking techniques, have often been measured by determining quantities and relative percentages of milk yields obtained by machine milking (prior to machine stripping), machine stripping, and hand stripping (Eyal, VolCANI and SHARAV, I958; GRUNFELD et al., I959; RiCORDEAU et al., I963; BOSC, I966; CASU, I967; MrKus, rg69; LABUSSIÈRE and RicordeaU, I970; Masar, I973; Kassalijski and Dimov, r973; Sharav, r973).

(1) Condensed from a paper presented by O. JATSCH and R. SAGI, I978 at the and International Symposium on Machine Milking of Small Ruminants, Alghero, Italy. 
Selection for improved machine milkability by measuring milk yield fractions is a difficult and time consuming task, and is not practical under commercial farm conditions. The use of easily identified phenotypic traits closely related to effective machine milkability could be practical bases for selection. SAGI and MORAG (I974) showed a strong relationship between udder conformation in ewes and their milk yield, and milk yield fractions. Their exploratory studies were based on a single observation which did not allow measurement of effects due to age, stage of lactation or management variables. The studies reported here were designed to measure these interrelationships.

\section{Procedures}

This study was carried out with the same flock used by SAGI and Morag (I974) which for this trial consisted of 229 Assaf and 40 Awassi ewes kept under the same management conditions. The flock was located at Neve Ya'ar, $32^{0} 45^{\prime} \mathrm{N}$, $35^{\circ}$ I $2^{\prime} \mathrm{E}$ where the average day and night temperatures, respectively, were $34.0^{\circ} \mathrm{C}$ and $19.8^{\circ} \mathrm{C}$ in August and $77.6^{\circ} \mathrm{C}$ and $7.8^{\circ} \mathrm{C}$ in January, and the annual rainfall was $560 \mathrm{~mm}$.

Lambs from 224 ewes were allowed to suck their dams for I5 to $30 \mathrm{~min}$ immediately after each milking to obtain milk not removed by thorough machine milking, machine stripping and hand stripping (i.e., complementary milk) which is the practice used in Israel as described by MoRAG, RAZ and EYAL, I970. Lambs were weaned from their dams when they reached $18 \mathrm{~kg}$ body weight. Ewes with twins or triplets were allowed to nurse only one lamb. The other lambs of the same litter were reared on ewe milk replacer as were lambs from 45 ewes who were weaned from their dams within one day post partum.

Data on milking performance was collected from twice daily milkings, every two weeks, from October 1972 to June I973. The a.m. and p.m. milkings occurred after $\mathrm{I} 6$ and 8 hour intervals, respectively. Milking management was the same as described by SAGI and MoraG (I974). Yield per milking was divided into quantities obtained by machine milking (MM), by machine stripping (MS), and by hand stripping (HS), and the total was designated as the dairy yield (DY) as defined by MorAg et al. (I973). Adaptability to machine milking was determined by the amounts and percentages of these fractions.

Ewes were milked until dairy yield decreased below $300 \mathrm{~g}$ per day. I ength of lactation was variable since no distinct lambing season was practised and many ewes lambed again before a previous lactation had been completed. Therefore, only data up to r3o days of lactation were analyzed.

Before each milking, the ewes' udders were classified into four types described

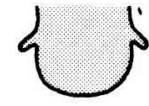

I

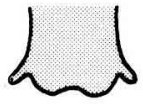

II

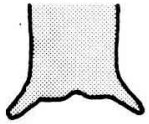

III

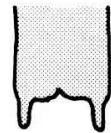

IV

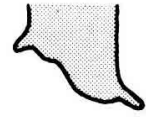

Z

FIG. I. - Schematic representation of udder types. Représentation schématique des types de mamelle. 
by SAGr and Morag (I974), plus an additional type characterized by nonsymmetrical udder halves (fig. I). Udder consistency was determined by palpation to determine whether they contained hard tissue lumps as described by Plommet (1973). In this respect, udders were classified as negative or positive, the latter without regard to the size of the lumps.

Data from the milk records were evaluated by least squares analysis (HARvEY, I975) using the following statistical model:

$y_{i j k l m n}=\mu+a_{i}+b_{j}+c_{k}+d_{l}+f_{m}+g_{n}+e_{i j k l m n} ;$

$y_{i f k l m n}=$ milking parameter of any animal within subgroup;

$\mu \quad=$ overall mean;

$a_{i} \quad=$ effect of $i^{\text {th }}$ lactation number $(i=\mathrm{I}, 2,3,4, \geqslant 5)$;

$b_{j} \quad=$ effect of $j^{\text {th }}$ udder type $(j=\mathrm{I}, 2,3,4,5)$;

$c_{k} \quad=$ effect of $k^{\text {th }}$ udder consistency $(k=\mathrm{I}$, negative; 2 , positive);

$d_{l} \quad=$ effect of $l^{\text {th }}$ breed ( $l=\mathrm{I}$, Awassi; 2, Assaf);

$f_{m}=$ effect of $m^{\text {th }}$ rearing system ( $m=\mathrm{I}$, suckling complementary milk; 2 , early weaned);

$g_{n} \quad=$ effect of $n^{\text {th }}$ Io-day intervals of lactation stage $(n=\mathrm{I}, 2, \ldots, \mathrm{I} 3)$;

$e_{i j k l m n}=$ sum of undefined effects (error term).

\section{TABIE I}

Effect of various traits on dairy yield and milk yield fractions in dairy ewes Signification statistique des effets des paramètres anatomiques et physiologiques sur la quantité de lait trait et sur son fractionnement lors de la traite mécanique chez la brebis laitière

\begin{tabular}{|c|c|c|c|c|c|c|}
\hline Trait & $\begin{array}{l}\text { Lactation } \\
\text { number }\end{array}$ & $\begin{array}{l}\text { Udder } \\
\text { type }\end{array}$ & $\begin{array}{l}\text { Udder } \\
\text { consis- } \\
\text { tency }\end{array}$ & Breed & $\begin{array}{l}\text { Rearing } \\
\text { method }\end{array}$ & $\begin{array}{c}\text { Stage } \\
\text { of } \\
\text { lactation }\end{array}$ \\
\hline Variable: & \multicolumn{6}{|c|}{ Analysis of variance ${ }^{1}$} \\
\hline Dairy yield a.m.. . . . . . & $* * *$ & $* * *$ & $* * *$ & * & NS & $* * *$ \\
\hline Dairy yield p.m. . . . . . & $* * *$ & $* * *$ & $* *$ & NS & NS & $* * *$ \\
\hline Machine milk a.m... . . . & $* * *$ & $* * *$ & $* * *$ & NS & $* *$ & $* * *$ \\
\hline Machine milk p.m. . . . . & $* * *$ & $* * *$ & NS & $*$ & $* *$ & $* * *$ \\
\hline Machine stripping a.m... . & $* * *$ & $* *$ & NS & NS & NS & $* * *$ \\
\hline Machine stripping p.m. . . & $* * *$ & $* * *$ & $* *$ & NS & NS & $* * *$ \\
\hline Hand stripping a.m. . . & $* *$ & $* * *$ & $* * *$ & NS & $*$ & $* * *$ \\
\hline Hand stripping p.m. . . . & $* * *$ & $* * *$ & $* * *$ & NS & NS & $* * *$ \\
\hline Machine milk a.m. (p. Ioo). & $* * *$ & $* * *$ & NS & NS & NS & $* * *$ \\
\hline $\begin{array}{l}\text { Machine milk p.m. (p. Ioo) } \\
\text { Machine stripping a.m. (p. }\end{array}$ & $* * *$ & $* * *$ & NS & $*$ & $* *$ & $* * *$ \\
\hline 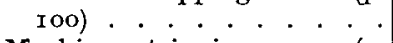 & $* * *$ & $* * *$ & NS & NS & NS & $* * *$ \\
\hline 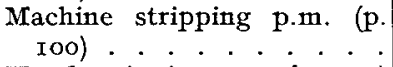 & $* * *$ & $* * *$ & NS & NS & ** & $* * *$ \\
\hline Hand stripping a.ni. (p. Ioo) & $* * *$ & $* * *$ & $*$ & NS & NS & $* * *$ \\
\hline Hand stripping p.m. (p. тоо) . & $* * *$ & $* * *$ & NS & $* *$ & NS & $* * *$ \\
\hline
\end{tabular}

(1) NS : not significant.

$\begin{aligned} * & : p<.05 \\ * * & : p<.01 \\ * * * & : p<.001\end{aligned}$ 


\section{Results and discussions}

The result of the analysis of variance are shown in table I. Among the traits tested, udder type, lactation number and stage of lactation were the major causes of variation in dairy yield and its fractions.

As shown in figure 2, the differences between breeds for any milk fractions (expressed as a percentage of the dairy yield) ranged from $0.8 \mathrm{p}$. Ioo for hand stripping at the $7: 00$ milking to $4.4 \mathrm{p}$. I oo for machine milk at the $\mathrm{I}_{5}: 00$ milking and were not large enough to be of practical or statistical importance. The dairy yield of the Assaf breed was I $4 \mathrm{~g}$ per day higher than for the Awassi breed
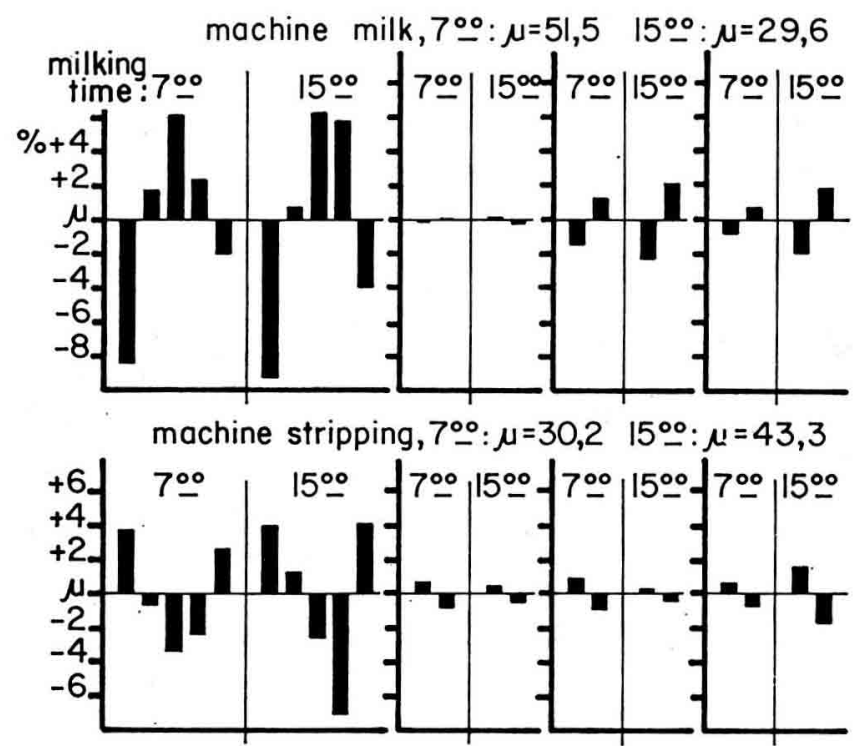

hand stripping, 700 : $\mu=18,3$ 15ㅇ: $: \mu=27,1$

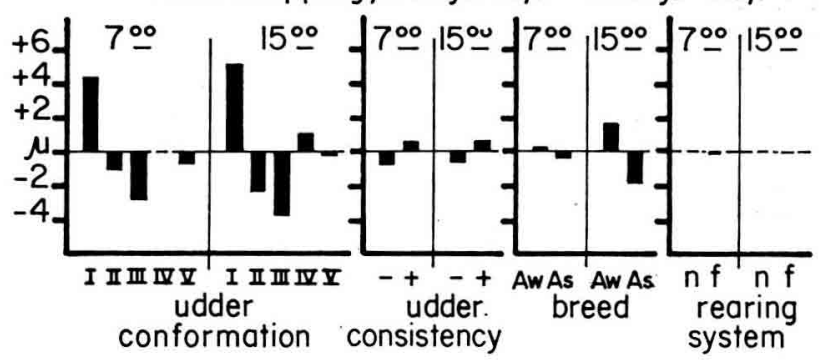

FIG. 2. - Percentage of milk fractions as influenced by udder conformation, udder consistency, breed, and rearing system.

Effets de la conformation de la mamelle, de la présence d'indurations intramammaires, de la race, et de la méthode d'élevage des agneaux sur l'importance relative des quantités dé lait recueillies au cours des différentes phases de la traite.
- : no indurations
Aw : Awassi
$n$ : suckling
+ : indurations
As : Assaf
$f$ : early weaned 
but this difference was not significant $(P>.05)$. This may indicate that upgrading the Awassi by cross breeding with East Friesian Milchsheep to create the new Assaf breed did not substantially affect milkability or yield.

There were no differences of practical importance in milk yield fractions or dairy yield between ewes due to effects of the lamb rearing methods. Ewes rearing one lamb by having it suckle twice daily after milking had similar yield and milkability as ewes whose lambs were removed within one day post partum. This agrees with the findings by MoRAG et al. (I970) and EyAI et al. (I972) of no negative effects on milk yield or milk ejection caused by allowing lambs to suckle after each milking. Since lambs were reared with complementary milk as the only liquid nourishment, this method of rearing can be highly recommended for the two Israeli breeds.

Udders with or without hard tissue lumps had similar percentages for milk yield fractions, however, those with lumps yielded I $88 \mathrm{~g}$ more milk per day. PLOMMET (I973) reported that lumps may result after infections of the udder by staphylococci and may contain inactive bacteria of that type. A possible explanation for the higher yield from ewes with udder tissue lumps could be that high yielding, previously infected ewes may be culled less frequently than low yielding previously infected ewes or that high yielding ewes are more susceptible to udder infections.

The relative amount of machine milk (MM) decreased and stripping milk (MS and HS) increased, with increasing lactation number (fig. 3). A similar effect was shown by JoHANSSON (I952) and WILKE (I960) who found slightly
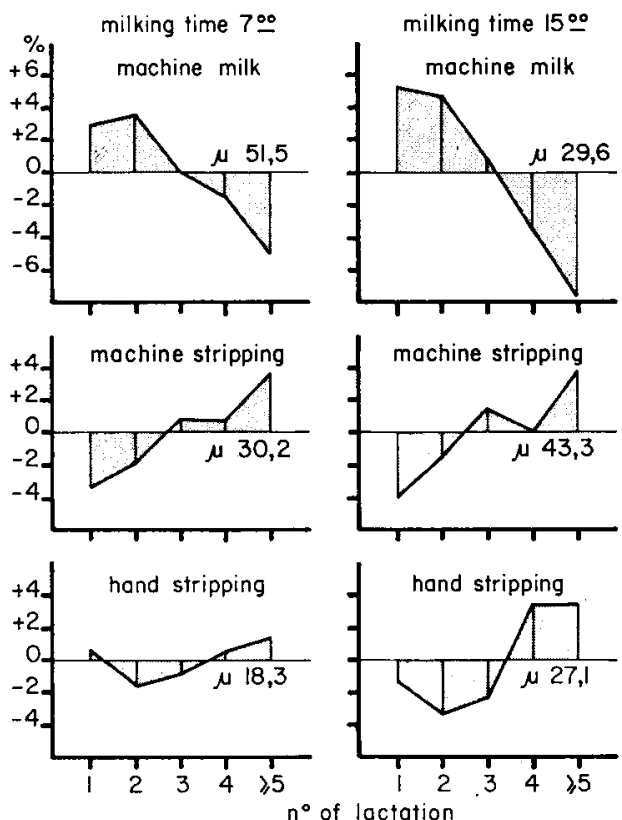

FIG. 3. - Effect of lactation number on the percentage of milk fractions.

Effet du nombre de lactations sur l'importance relative des quantités de lait recueillies au cours des différentes phases de la traite. 


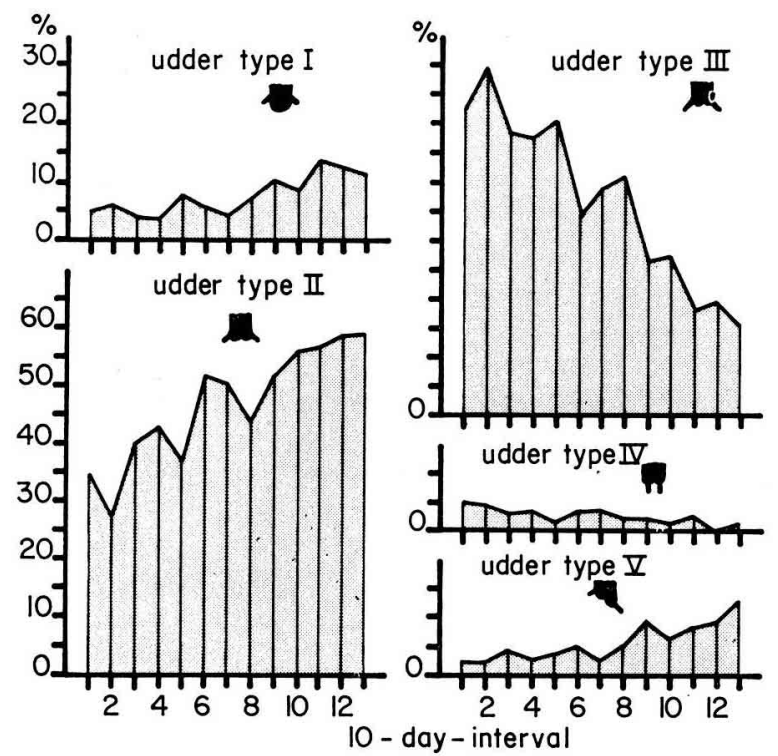

FIG. 4. - Distribution of udder types during the course of lactation.

Distribution des types de mamelle au cours de la lactation.

TABLE 2

Correlation coefficients between milk yield fractions at each of the two daily milkings, and the same variable on a daily basis

Coefficients de corrélation entre lait total et pourcentages de lait obtenus au cours des différentes phases de la traite à chacune des deux traites quotidiennes d'une part et les mêmes paramètres pour la production quotidienne

Milk yield fractions

At each milking interval

I6 $h$ interval:

Dairy yield (DY) (kg) . . . . . . . . . .

Machine milk (MM) (p. Ioo) . . . . . . . .

Machine stripping (MS) (p. IOo) . . . . . .

Hand stripping (HS) (p. Ioo). . . . . . . .

8 interval:

Dairy yield (DY) (kg) . . . . . . . . . .

Machine milk (MM) (p. roo) . . . . . . . .

Machine stripping (MS) (p. Ioo) . . . . . .

Hand stripping (HS) (p. roo) . . . . . . .

On a daily basis

\begin{tabular}{|c|c|c|c}
\multicolumn{3}{|c}{ On a daily basis } \\
\hline DY & MM & MS & HS \\
\hline 0.98 & 0.96 & & \\
& & 0.93 & \\
0.91 & & & \\
& & & \\
& & & \\
& & & \\
& & & \\
& & & \\
\end{tabular}

All correlations are significant $(\mathbf{P}<$. .oor $)$. 
better milkability in cows during the first lactation compared to later lactations. On the other hand, Bosc (I966) found in Lacaune ewes that both the absolute and relative quantities of milk obtained by stripping were higher in the first lactation.

Ewes with type III udders had the best distribution of milk yield fractions with machine milk being $57 \mathrm{p}$. I 00 and $36 \mathrm{p}$. Ioo of the dairy yield at the a.m. and p.m. milkings, respectively (fig. 2). Under the same condition, ewes with

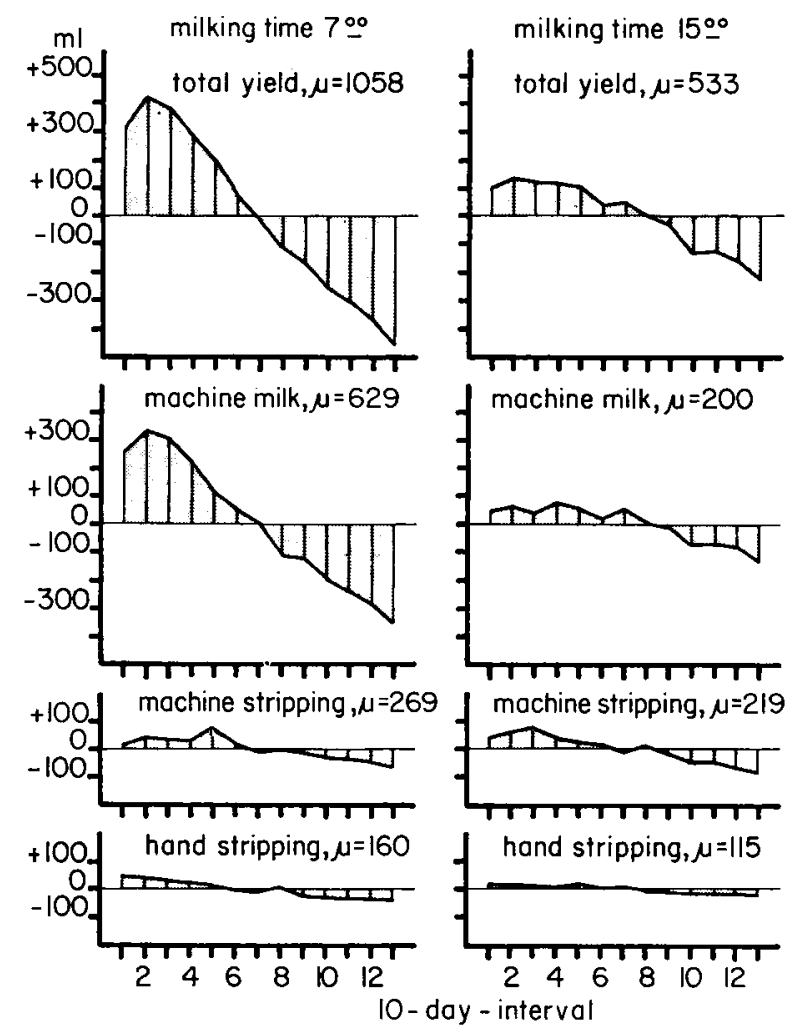

FIG. 5. - Effect of stage of lactation on the amounts of dairy yield and milk fractions.

Effet du stade de lactation sur la production totale de lait

et sur les quantités de lait recueillies au cours des différentes phases de la traite.

type I udders gave only $43 \mathrm{p}$. Ioo and $2 \mathrm{I}$ p. roo of their dairy yields as machine milk.

There were no significant differences in average dairy yield between udder types II and III (I,747 and I,74I $\mathrm{ml}$ /day, respectively) nor among udder types $I$, IV and $V(I, 462, I, 509$, and $I, 494 \mathrm{ml} /$ day, respectively). However, the average yields of ewes with udder types II and III were significantly different $(\mathrm{P}<.05)$ from those with udder types I, IV and V. The latter three udder types represented only I7 p. roo of all observations.

These relationships between udder type, dairy yield and milk yield fractions, 
although not as dramatic as in the earlier investigation, would be of great value to the improvement of dairy sheep if udder type was persistent throughout lactation. Unfortunately, this is not the case. As shown in figure 4 , the frequencies of udder types $I$, II and $V$ tend to increase during the course of lactation whereas udder types III and IV are more frequent in early lactation. Since "udder type" is not persistent throughout lactation, selection for this trait cannot be carried out effectively without considering the stage of lactation. Therefore, the exclusive preference of udders of types III and IV, as suggested by SAGI and Morag (I974), cannot be recommended. However, ewes with damaged udders (type V) and those with a bad suspensory apparatus (type I) should be culled not only because of poor milkability but because teat cups tend to fall off during milking.

The lactation curve of dairy yield from ewes, shown in figure 5 , resembles a cow's lactation curve. Peak yield occurred at the end of the second ro-day interval. The curve for dairy yield at the p.m. milking after an 8-hours interval declines less steeply than that for the a.m. milking after a I6-hours interval. The slope of the curve for dairy yield and machine milk fractions are almost identical whereas absolute amounts of strippings decline very slowly and almost linearly in accordance with MASAR's results (I974).

TABLE 3

Correlation coefficients between the absolute and relative milk fractions at each of the daily milkings and the total daily yield

Coefficients de corrélation entre le lait total quotidien et les quantités et pourcentages du lait obtenus au cours des difféventes phases de la traite (traite du matin: ${ }_{16} 6$ d'intervalle, traite du soir: 8 h d'intervalle)

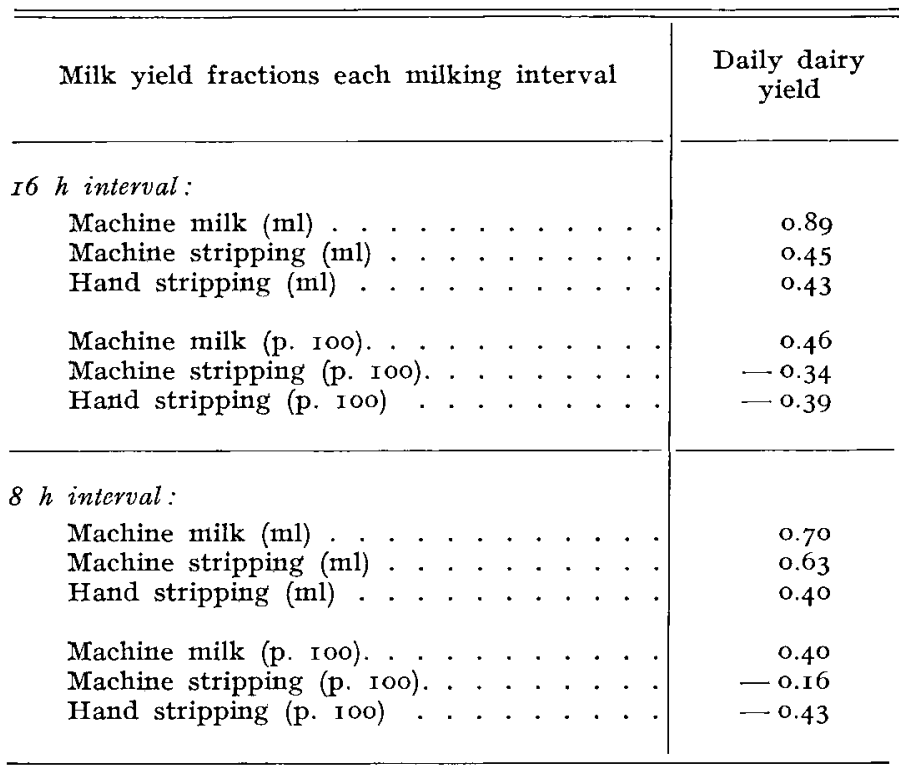

All correlations are significant $(\mathrm{P}<$.oor $)$. 
It would be interesting to know if recording milk yield fractions only once a day would be representative and reliable for selection purposes. Correlation coefficients, given in table 2 , between daily parameters and those measured after I 6 hours and 8 hours intervals, are very high. However, the recordings made after the longer interval were the ones most highly correlated with daily values.

Correlations between daily dairy yield and milk yield fractions in absolute and relative terms, given in table 3 , indicate that high yielding ewes are better milkers as well. This is an accordance with MASAR (1976). In addition the amount of machine milk fraction after the long milking interval is correlated with the percentage of daily machine milk $(r=+0.72)$, with the percentage of daily machine stripping $(r=-0.58)$ and with the percentage of daily hand stripping $(r=-0.56)$; all the correlations were significant $(\mathrm{P}<.00 \mathrm{I})$. Thus, the amount of machine milk fraction seems to be a parameter that should be tested for its genetic value as a selection parameter since it is easy to measure and can be used whether or not simplified milking methods are used in the flock.

Accepté pour publication en mars 1979.

\section{Acknowledgements}

We are grateful to Dr. W. G. MERRII, for assistance in preparing this manuscript.

\section{Résumé}

\section{Influence de l'adaptabilité à la traite mécanique sur le rendement en lait et ses composantes chez les brebis laitières}

Les effets de la race, de la méthode d'élevage, de la conformation de la mamelle, de la présence d'indurations intramammaires, du nombre de lactations et du stade de lactation sur la quantité de lait et sur l'adaptation à la traite mécanique sont évalués sur la base des différentes fractions de lait recueillies lors de la traite mécanique de brebis laitières de race Awassi et Assaf.

La quantité totale de lait et l'adaptation à la traite mécanique sont affectées significativement par la conformation de la mamelle; par contre, la race, la méthode d'élevage et la consistance de la tnamelle ne sont pas sources de variance significative. La conformation de la mamelle définie selon 5 types caractéristiques varie au cours de la lactation. L'adaptation à la traite mécanique diminue avec l'âge de l'animal et le stade de lactation. Ces observations doivent être prises en considération pour améliorer les critères de sélection des brebis laitières destinées à être soumises à la traite mécanique.

\section{References}

Bosc J., I966. Progrès récents et problèmes de la traite mécanique des brebis. Ann. Nutr. Aliment., 20, 193-230.

CASU S., I967. La pecora Sarda e la mungatura meccanica. Riv. Zootec., 40, 32-48.

Eyal, E., Volcani R., Sharav E., I958. Milk secretion and milking efficiency in sheep. Hanoked, 40, 7-10 (in Hebrew). 
Eyai, E., Folmax Y., MoraG M., r972. Lamb production in frequently lambing dairy sheep. Agricultural Research Organization, The Volcani Center, Bet Dagan, Israel, Sevies No. $22 I 6$ E (Polycopy).

GRUNFELD J., Volcani R., Eyal E., I959. Quelques observations sur l'adaptation de la brebis Awassi à la traite mécanique. Hanoked, $\mathbf{4 2}$ (in Hebrew).

HARvey W. R., I975. L,east-squares-analysis of data with unequal subclass numbers. $A g r i$. Res. Service, US Dept. of Agriculture.

JATSCH O., SAGI R., I978. Effects of some anatomical traits on dairy yield and milk fractionation on dairy ewes. 2nd International Symposium on Machine Milking of Small Ruminants, Alghero, Italy.

JoHANssov I., 1952. Studies on udder evacuation in dairy cows. II. The amount and composition of the residual milk after normal milking. Acta. Agric. Scan., 2, 82-102.

Kassalijski M., Dimov S., 1973. Quelques résultats des problèmes relatifs à l'étude d'un "Système " de convoyeur mobile de traite de brebis. Symposium sur la traite mécanique des petits ruminants, Millau, France.

Labusstére J., Rrcordeau G., I970. Aptitude à la traite mécanique des brebis de race Préalpes du Sud et croisées Frisons $\times$ Préalpes; étude à différents stades de la lactation. $A n n$. Zootech., 19, I59-190.

LABUSSIERE J., 1969. Importance, composition et signification des différentes fractions de lait obtenues successivement au cours de la traite mécanique des brebis. Ann. Zootech., 18, I69-I 85 .

MASAR M., I973. La traite mécanique à l'aide du dispositif tchécoslovaque DZO 20. Symposium sur la traite mécanique des petits ruminants, Millau, France.

MASAR M., I974. Study of milking intensity in machine milking of Merino and Valaska ewes. Scientific Works of the Research Institute for Sheep Breeding at Trencin, 7, 59-66.

MASAR M., I976. Relationship between milk yield in machine milking (during I 20 sec) and the total milk yield in lactating ewes. Scientific Works of the Research Institute for Sheep Breeding at Trencin, 8, 43-48.

Mrkus M., I969. Hand stripping at machine milking in relation to udder measurements, lactation days, and certain other traits. Zivocisna vyroba, 14, 827-834.

MoraG M., RAz A., EYAI E., I970. Mother-offspring relationships in Awassi sheep. IV. The effect of weaning at birth or after I 5 weeks, on lactational performance in the dairy ewe. J. Agric. Sci. Camb., 75, I83.

Morag M., Sagi R., Eyal E., Folman Y., I973. The definition of milk yield and milk fractions in lactating animals. J. Agric. Sci. Camb., 81, 361-363.

Ploмmeт M., I973. Mastitis and machine milking. Symposium sur la traite mécanique des petits ruminants, Millau, France.

Ricordeau G., Martinet J., Denamur R, i963. Traite à la machine des brebis Préalpes du Sud, importance des différentes opérations de la traite. Ann. Zootech., 12, 203-225.

SAGI R., MORAG M., r974. Udder conformation, milk yield and milk fractionation in the dairy ewe. Ann. Zootech., 23, 185-192.

Sharav E., I973. Comparative experiment on four teat cups for sheep. Symposium sur la traite mécanique des petits ruminants, Millau, France.

WILKF G., I960. Die Melkbarkeit; ihre Abhängigkeit von der Euterform unf ihr Einfluss auf die Laktationskurve. Arch. Tierz. Züchtbiol., 74, 48-86. 